6.

\title{
Paris, a Contested Construction of Metropolitan Space
}

\author{
Christian Lefèvre
}

\section{Introduction}

This chapter tells the story of the difficult and contested efforts to reconstruct Paris as a metropolitan space. Covering the period of 2000 to the present, it focuses on the search for a collective actor and the production of collective action (e.g. public policies) through the quest for alliances between players, be they the central State, local governments or business associations.

Following a neo-weberian approach (Le Galès 2002), the author considers cities as the locus of various interests and groups in conflict which are relatively integrated, notably through governance instruments. In that approach, political power has a relative autonomy from these interests. In this theoretical framework, the study of collective action and collective actor considers power as "the capacity to act" (Stone 1993) and is interested in the building of coalition(s) of players in terms of growth coalitions (Logan and Molotch 1987) urban regimes (Stoker and Mossberger 1994; Stone 1993) or other configurations.

More specifically, the chapter concentrates on the relationships between core metropolitan stakeholders through the analysis of four political initiatives aiming at building collective action and territorial leadership at the metropolitan scale. Each initiative was carried out by a specific player (the regional council, the city of Paris, and/or the State). Notably, they met with a relative failure, because each one of them had to accomodate two crucial processes, globalisation and decentralization. These themes were understood and interpreted differently. Not surprisingly, as these cases will reveal, metropolitan governance has proven to be a highly conflictual issue among players, as we shall see (Lefèvre 2017).

It is also important to note that the four initiatives - some of them being pursued simultaneously and some subsequently - have taken place in a period of electoral turmoil. No less than two national elections, three municipal elections and three regional elections occurred. Each have had considerable consequences for these initiatives. The elections all crystallised conflicts regarding the construction of metropolitan space, and had impacts on the ability to achieve success.

This chapter is the outcome of a participant involvement of the author in the various events which have taken place since the beginning of 2000, around the issue of metropolitan governance in the Paris city region. This involvement has taken several forms. First direct independent research was carried out for the city of Paris, the Region Ile de France, the Regional Planning Agency, the research center of the Caisse des Dépôts, etc. Second direct involvement in working groups, scientific 
committees and advisory councils set up by most public authorities (city of Paris, Paris Métropole, central State). Some of the most significant publications on the issue are listed in the references.

\section{The Metropolis is the Region: More a political slogan than a political process}

\section{More Powers to the Region}

Since 1982, the various decentralisation acts have gradually transferred more and more powers to local governments (municipalities, départements and Regions), being very cautious not to advantage a specific tier and maintaining the constitutional rule of no hierarchy among governmental levels. In that context, the Region Ile de France had a special status because some of the powers which had been transferred to the Regions elsewhere had been kept by the central State based upon the argument that the the area is of crucial importance for the whole nation. In particular, public transport and planning had not been transferred.

Arguing that the regional territory was the relevant scale to address the most urgent problems of the development of the Ile de France, and that it was not acceptable that some powers, which had already been given to the regional councils in the rest of France, were still in the hands of the State, the regional council has constantly asked to be treated the same way, i.e. as a normal Region. In adddition, all regional executives have claimed that "the metropolis is the region", meaning that the territory covered by the regional administration, more or less matches the functional metropolitan space. This had an essential implication, that it was useless to try to establish a new authority at the metropolitan level (see section 4) because it already existed and the rationale should instead be to increase the powers and resourses of the Region.

\section{BOX [about here] and figure 1}

The Institutional and Territorial Context

Gradually, the Region gained powers and resourses, and in 2005, two major competences, public transport and planning were transferred. The transfer of public transport meant that the regional council would control the Syndicat des Transports d'Ile de France (STIF), a joint authority grouping the Region, the eight départements, and a few representatives of other local authorities. Indeed, it held the majority of the seats on the board, chairs it, and has a casting vote. The State who chaired and controlled the STIF before has, in the process, disappeared since it is no longer part of the executive board and has only one seat with no voting rights. 
The transfer of planning powers was finally actualized the same year, although it had been authorized ten years before by a National Planning Act. Until then, the Ile de France master plan was elaborated and approved by the State, with local governments having an advisory role only. In 1994, the power of the State was real, as expressed by the imposition of the then current master plan, i.e. the Schéma Directeur de la Région Ile de France (SDRIF) by the State, despite the unanimous rejection of it by local governements. It was this plan which was in operation in 2005 when the regional council decided to revise. However, the State maintained a role in that process since it was to be 'associated' with the elaboration of the master plan, and had to approve it overall to make it fully binding. The transfer of the master plan to the Region, therefore, was a significant move to make the regional council stronger since the SDRIF was a prescriptive document. All other planning documents of all other local governments had to comply with it and it was binding against third parties (opposable aux tiers). Therefore the Region gained a powerful planning tool to master its development.

Over time, the regional council gradually gained new competences: skills, the management of high schools, the management of European structural funds and the leadership on economic development policies through a series of decentralisation acts. However, it failed to garner two important powers, which it considered to be of metropolitan interest: control of mobility as a whole and housing. In 2008, the regional council established a commission called 'Scenarios for the Ile de France Tomorrow' (CRIF, 2008). This commission sought to extend the powers of the STIF to the major expressways, taxis and logistics. It also proposed the creation of a new joint authority on housing in which the Region would have had an important role. Both proposals did not get the support of other players and were not even discussed seriously.

\section{The Contestation of the Regional Power}

The increase of regional powers did not come smoothly. In fact, the Region had to fight to get them and be able to use them.

Although control over the STIF had been established by the 1999 Act on Urban Renewal ${ }^{1}$, it did not become a reality until 2006. The State proved to be very reluctant to transfer its powers to the regional council. The main conflict was over the funding of the public transport authority and its relationship with the two major operators, the National Railways (SNCF) and the RATP, both controlled by the State. It took six years to solve the conflict. Since then, relations between the Region and the State have not been good, particularly when the national government was controlled by the conservative party and the Region was controlled by the socialist party. As we shall see below, the fight has been over the transport policies carried out by the Region. The State and other players, notably business associations, accused the Region of pursuing a policy which might be good for a 'provincial' city, but not for a global metropolis. 
In 2005, the regional council decided to revise the master plan (SDRIF). After a long process of elaboration, the new plan was approved by the regional council in october 2008. According to the legal procedure, it was then transmitted to the State in order to make it fully legal. But the State refused to endorse the plan and the process was stopped.

The State argued that the economic dimension of the plan failed to take into consideration the international competition between the Ile de France and major global cities. For instance, it indicated that the annual growth forecast of 2 percent and 28,000 jobs mentioned in the plan were largely unsufficient to maintain the position of the region in the top global city rankings. It thus urged the regional council to adopt a plan with at least a 4 percent growth rate and an increase of 60,000 jobs per year. More specifically, the State commanded that the Region integrate the extension of the La Défense $\mathrm{CBD}^{2}$ and the new public transport scheme proposed by the government (Subra 2012) (see below), into the plan. This new public transport scheme was indeed a matter of conflict between the State and the Region because the Region had already approved another project, less ambitious and less competitively oriented than the State's one.

Beyond the battle over the numbers, the sources of conflict between the State and the regional council were deeper. In fact both had opposing conceptions of the future of the Ile de France. For the regional council, in which the Green party had a relatively important weight, the future of the region lay in a new mode of development based on the green economy and energy transition. The master plan thus paid significant attention to these considerations. In addition, the fight against social and territorial disparities was also a key element of the plan. The Region claimed that to achieve this, the priority was to better balance its spatial and economic development in favour of the east, which clearly meant not to extend La Défense in the west, which was already perceived to be too congested. Instead, the Region sought to develop the eastern part. This seriously contradicted the views of the State.

The state's position was supported by the major business associations and local governments from the right, notably those located in the west of the region and in particular those concerned by La Défense. They believed that the regional council did not take international competition seriously enough and as a result, would dangerously undermined economic growth and the competitiveness of the metropolis. Supporters of the master plan were the Region, the city of Paris, the leftist départements and a few municipalities. Their support was not only based on the sharing of the same conception of the development but on the fact that the State's decision to reject the plan was considered an attack on decentralisation itself.

Following the rejection of the master plan by the State, the regional council had no other option than to elaborate a new one, taking into consideration the criticisms made by the State. A new master plan was thus elaborated and approved in 2013. Although it was slightly different from the first one, it continued to assert the necessity of changing the mode of development in the region, by starting an "ecological, economic and social transition" (Conseil régional d'Ile de France 2013). The objective of adding 28,000 jobs per year was also maintained. The 2013 plan was supported by the same players as 
in 2008 and opposed by the same actors, with the exception of the regional chamber of commerce which stated that although it did not like it for the same reason as before, it did not want to block it. The plan was approved by the State and thus became law. But between 2008 and 2013, many things had changed, with implications for the plan. The global economic crisis of 2008 made the hypothesis of an annual 4 percent growth rate less credible, a compromise was reached about the public transport scheme (see below), and the State was now controlled by a new progressive political majority more inclined to compromise and to respect the 'spirit of decentralisation'.

\section{The Failure of Building a Regional Coalition}

If the Region has gained some powers over the last two decades, it is largely because decentralisation has been an on going process all over the country and not because of the political action of the regional council or other players. In fact, the Region has proved its incapacity to become a territorial leader or at least a federator, despite the recurrent rhetoric of its executives. Indeed, to become such a leader, the Region should have built and led a coalition of players, but this has never worked. Several reasons explain this situation.

First of all, leadership of the Region is very much contested by other powerful actors, first of all the State and the city of Paris. Alongside of this are the départements and municipalities, many of which, share the same position. No one wants a strong Region who could be a political rival (to the State and Paris) or have power over the other local authorities. The result has been an informal coalition of all these players, which successfully limited the Region powers.

Second, the Region has been unable to create a consensus around an agenda to build the future of the Ile de France area. Between 1998 and 2016, it was controlled by a political alliance dominated by the Socialist party. This alliance defended an agenda where the issues of social and territorial inequalities, and ecological transition were put to the front. This agenda got the support of the city of Paris upon the election of a Socialist mayor in 2001, and several progressive authorities (three or four départements of the south, north and east depending on election results over time). But at the same time, it was also opposed by powerful players like the State (controlled by the conservative party between 2002 and 2012), the three or four conservative départements of the west and north, many municipalities, and all major business associations like the CRCI and the Medef who wanted economic competitiveness to be the first priority. The result has been a fairly balanced system of alliances in which no one can prevail. By and large this has produced a stalemate.

Finally, the Region has had difficulties producing strong leadership within the coalition in power, composed of the Socialist party, the Communist party, the Greens and some minor leftist parties. In the French institutional system, the regional executive is elected by the regional councillors and must therefore reflect the composition of the winning alliance. Although the regional council had 
been chaired by the same President, a member of the Socialist party, from 1998 and 2016, the Communist party and the Greens had important vice-chairmanships, notably in planning and transport. Yet, these parties were, at the same time, in competition within the executive and were opposed to each other on specific issues and orientations. For instance, the Communist party had aways been a strong supporter of economic growth because it was supposed to create jobs. As such they were not keen to support the agenda of ecological transition and slow growth advocated by the Greens. The result has been a weak executive and a weak President whose major task has been to keep the coalition together, rather than to push for more powers for the Region.

\section{Paris’ Initiative: From the Metropolitan Conference to Paris-Métropole}

\section{Building Metropolitan Space by Voluntary Cooperation}

In 2001, just after his election, the new socialist mayor of Paris, B. Delanoë, created a new political position within his administration: a deputy mayor in charge of territorial cooperation. The objective was to try to breakdown the perceived "arrogance of Paris", while endeavoring "to make Paris cross its périphérique", the ring road around the city, to engage in dialogues with the adjacent local authorities in order to cooperate in resolving some of the most important common problems. Clearly the first step was to define what these problems were. For the city of Paris, the priority was the fight against the social and territorial inequalities that globalisation was accused of producing. Yet for the mayor it was clear that in order to achieve this, it was necessary to think "metropolitan" because "today, the Parisians, as much as the Francilians (i.e. inhabitants of the Ile-de-France region), believe their city to be at the scale of the whole metropolis. Transport, safety, housing, environment, solidarities, economic growth... A metropolis is all the more performing if it is inclusive." (Extramuros, September 2002, no page number)

In order to start such a dialogue between the city of Paris and local authorities, the mayor appointed a deputy mayor, member of the Communist Party, Pierre Mansat. This was no coincidence since most of the adjacent localities were at that time controlled by the Communist Party. Thus it was considered easier for the dialogue to be between local executives of the same political leaning, and more likely to lead to success. In the first years of its mandate, Pierre Mansat signed several agreements of cooperation with several municipalities and départements on specific topics (urban development, mobility, etc.). The point of these exercises, was to build trust between the central city and the suburbs, given that Paris had been accused, not without reason, of exporting its 'negative externalities' (waste treatment plants, cemeteries, etc.) to the peripheries. By and large, the new behavior of the central city was welcomed and appreciated by most local authorities. 
To go further, in 2006, the city of Paris decided to launch an important initiative to promote cooperation, through the creation of a metropolitan conference. It was open to all local authorities, and all mayors and executives had the same political weight, regardless of the demographic importance of their constituency. Thus it was premised on the principle of 'one local authority, one vote'. The idea of this metropolitan conference was to build agreement on what the most important common problems were, and to create an instrument of governance to produce policies to address them. It was clearly a bottom up approach in the definition of problems, policies and the building of instruments to tackle them.

At the beginning, only few local governments, mainly from the socialist and communist parties, joined the conference. However some important municipalities controlled by the center-right also agreed to participate. The conference held seven meetings between 2006 and 2008 on various topics: housing, transport, economic development and a final meeeting on the governance of the metropolitan area. During these two years, more and more local governments joined, but still largely from the left of the political spectrum.

In the 2008 municipal elections, there was no change in the political balance at the regional level. The mayor of Paris was comfortably reelected with about 57 percent of the votes. The metropolitan conference then convoked a 'General assembly of the agglomeration' which was attended, for the first time, by all the political leaders regardless of their political affiliation. The minister of Grand Paris (see section 3 below) was also present and concluded the meeting.

The major decision taken was an agreement to create a joint authority called Paris Métropole (PM), which came into being in early 2009. At first PM was composed of the same municipalities who participated in the metropolitan conference. This meant that the new authority was dominated by the left, since most conservative authorities boycotted it. But gradually it gathered all the important local governments of the core area (see Figure 2). Paris Métropole was a very weak authority, with no powers and very limited resourses. Its main objective was to maintain the dialogue between local governments and to launch a few actions aimed at creating a feeling of belonging to the metropolitan area. In all these activities, PM was very cautious in not defining the perimeter of the metropolis. (Figure 2 here)

In 2010, PM established a committee of partners in order to associate the economic milieus and civil society to its works. This committee was chaired by the regional chamber of commerce and involved only a few firms, notably the public utilities and construction sectors, which had a direct interest in the development of the metropolis.

Between 2009 and 2012 PM launched several events and campaigns to promote the metropolitan idea. However, in 2012, it began to go into decline and subsequently disappeared with the creation of the Métropole du Grand Paris in 2014, as we shall explain below. 
Until 2011, local authorities controlled by the conservative party refused to join Paris Métropole on the ground that it was an initiative launched by the city of Paris to legitimize its leardership on the metropolis with a political agenda (the fight against social and territorial inequalities) they did not share. They claimed that economic development based upon an enhancement of the international competitiveness of the Paris-Ile de France area should also be a priority. At the peak of the conflict, they even tried to create another association of local authorities, called Ile de France Métropole, but it never really came through.

The State, although not clearly against Paris's metropolitan conference initiative, stated that it was insufficient in the production of adequate policies to tackle the major problems of the area. From 2008, with the launching of the Grand Paris Project (GPP) - which will be discussed in the next section - it acted as if the Paris initative did not exist.

The Region, although of the same political leaning as the city of Paris, was careful to state that "the Region is the Metropolis". By this, they clearly meant that the metropolitan conference and Paris Métropole could in no way become an institutional substitute for the regional council. Indeed, throughout the initiative, the Region was very much on the defensive, participating only reluctantly in the process.

As for the business associations, they kept a position of neutrality, considering the Paris initiative as a purely politician operation. Even after the creation of the committee of partners in the Paris Métropole, their attitude did not significantly change. Notably, as we shall see, they were more keen to support the Grand Paris Project initiated by the State. As a public body, the regional chamber of commerce agreed to chair this committee, but was not very active within the body. Believing instead that the economic players should have been more involved in the board of the joint authority, instead of occupying a "folding seat".

After 2011, the conservative authorities decided to join the new institution, only after the compromise reached by the Region and the State over the Grand Paris Express in January 2011 (see section 3), and when the by-laws of the new authority clearly articulated a position of political neutrality in its executive (achieved with an annual political alternance between left and right).

Although the Paris Métropole was gaining membership, to the extent that by 2012 almost 200 local authorities were involved, representing more than 7 million inhabitants, it continued to have difficulties. The varied and often conflicting positions defended by it's members prevented it from becoming more than a simple arena of discussion and often found itself to be a body in dispute, incapable of achieving compromise on significant issues. This situation culminated in 2012 when it launched a debate on the governance of the metropolitan area.

In 2012 an intense internal debate on the governance system that the metropolis ought to adopt was launched within Paris Métropole. Three scenarios were proposed (Paris Métropole 2012): 
i) an 'integrated' metropolis, i.e. governed by a strong institution with limited powers and resourses to its member municipalities ;

ii) a 'concerted' metropolis, i.e. a metropolitan body whose powers and resourses would be accrue gradually, depending on negotiations and compromises ;

iii) a 'federated' metropolis, i.e. governed by an institution which would be a federation of strong municipal joint authorities.

The newly elected Socialist government asked Paris Métropole to present a proposition to reform of the governance of the metropolitan area. After several months of discussion, the joint authority proved unable to come to an agreement. The various lines of conflict had to do with the new allocation of competences and resourses to be given to the various institutional players. Each one of them defended the powers and resourses that had been given by the various decentralisation acts, and were unwilling to give those up or share them.

Following this, Paris Métropole slowly went into decline. In 2014, after the establishment of the Métropole du Grand Paris, it changed its name into 'Metropolitan Forum of Grand Paris' and started to lose members.

\section{The failure to build a territorial leadership}

Three major reasons may explain the failure of the Paris initiative and the disapearance of Paris Métropole.

First of all, the leadership of the central city is contested by strong players such as the State, the Region and the powerful local governments to the west. The State is afraid that Paris could become too powerful and be a political rival to its domination. Local governments do not want to have a metropolitan institution which would be controlled by the economically and politically most important municipality of Paris. This position was also shared by many local authorities of the same political leaning as Paris. They prefered the idea of the federated metropolis, because it would assure a better balance of power and would respect one of the core principles of decentralisation: no hierarchy between local governements. The view of the regional council was almost the same. Its reluctance to support the initiative was largely founded on the 'doughnut syndrome' in which it feared that the core of the regional territory would be controlled by a metropolitan institution, whatever its form, and which would only leave the management of the peripheries to the Region.

The second reason concerned the political agenda of the initiative. Clearly for the initiators of the metropolitan conference and Paris Métropole, the major issues of concern were those brought about by the Globalisation process or at least accentuated by it, social and territorial inequalities, which had increased in the last decades. For the State (at least until 2012) and many local authorities of the west (the richest part of the region), the priority was the economic competitiveness of the 
metropolis, assuming that with a better economy, social inequalities would diminish. In such a situation where both sides hold equal weight, no political consensus or even compromise could be achieved.

Finally, the success of the initiative was challenging from the start. The national and local elections which took place in 2008 (municipal elections), 2010 (regional), 2012 (national), 2014 (municipal), 2015 (regional) were looked upon strategically to advantage the stakeholders. Each side counted on its success to either strengthen or stop the process, a situation which brought uncertainties and made the outcome of the initiative too dependent on the conjecture.

\section{The Grand Paris, a Project of the Conservative Government}

In the summer of 2007, Nicolas Sarkozy, the newly elected President of the Republic, gave a speech in which he remarked that the Paris metropolis was the only large city in France not to have an "urban community" (communauté urbaine) ${ }^{3}$. This speech was the first sign of a willingness for the State to have a say in the governance of the Paris area.

\section{The State Takes Over}

This was soon followed in march 2008 by the establishment of a specific Ministry, the State secretariat for the development of the capital region, in charge of proposing a public transport scheme (called the 'Big 8') and a new governance arrangment for the the whole region. This is what has been defined as the Grand Paris Project (GPP) of the national government. By using the term 'capital region', the national government voluntarily avoided specifying a perimeter, which could either be the region Ile de France, something smaller or even larger.

The GPP was launched with the purpose of "making the capital region a world city (Ville Monde) capable of competing with other global cities, notably London" (Présidence de la République 2008 no page number since it is a press release). For the State, the big 8 - which was an automatic subway of about $220 \mathrm{~km}$., whose main purpose was to inter-connect airports and the major economic and scientific clusters of the region (including the city of Paris) - was needed, for Paris to achieve global status. The total financing needed for the project was estimated to be about 25 billion EUR.

To implement its project, the State - which had a strong majority in the National Assembly imposed the Greater Paris Act in 2010. This act gave significant powers to the State over the development of the Paris metropolis with the creation of three instruments :

i) the Société du Grand Paris (SGP), a public company in charge of building the 'Big 8' and developing the areas around the 65 stations of the network. It would be controlled by the State 
who would hold the majority of seats in its board. As such it would not be a part of the STIF, the regional public transport authority controlled by the Region;

ii) the Etablissement Public d'Aménagement Paris-Saclay, (EPAPS), a public development corporation in charge of developing a world cluster of knowledge in the south west of the Ile de France, which would be controlled by the State through appointment of its President and CEO; and

iii) the Territorial Development Contract (CDT), a new planning tool that would be signed by the State and municipalities (i.e. other local authorities like the départements and the Region cannot sign them) to develop specific areas around the Grand Paris stations.

By the Grand Paris Act, CDTs would become strong planning instruments because they did not need to comply with the regional master plan (SDRIF). Therefore, with a new ministry, a new public company, the SGP, a new development corporation (Saclay) and new planning tools (CDT), the State had built the necessary governing instruments to implement the GPP.

\section{The Battle over the Grand Paris Project}

The GPP and notably its transport dimension, the big 8 and the SGP, received the support of the wealthy and conservative local governments located in the west of the region, and the major business associations and groups (chambers of commerce, Medef, PICE), which all shared the 'world city' vision of the state. They claimed that the regional council had proved incapable of using its public transport powers to create the infrastructure that the Paris metropolis urgently needed in order to maintain its rank at the top of the world cities hierarchy.

Not surprisingly the GPP was opposed by the regional council and most local governments controlled by the left, including the city of Paris. They all supported another project, Arc Express. Arc Express was proposed by the regional council, and was integrated in the new master plan in elaboration. Arc Express, in contrast to the big 8, focused on the improvement of services between the suburbs and existing lines, and was much less costly. Its supporters stated that Arc Express would be more responsive to the mobility difficulties of inhabitants (Gilli, 2014), the most urgent priority, because it could be used to reduce the social and territorial inequalities which plagued the region.

With the creation of the SGP (controlled by the State and autonomous from the STIF), the regional council accused the State of violating the decentralization laws regarding public transport and refused to take its seat on the SGP board. It was followed by similar behaviour by the municipality of Paris. The situation thus produced, a stalemate. 
Although the GPP was backed by many players (the big business associations, conservative local authorities), the State's intiative was also fought by powerful local authorities, notably the city of Paris and the Region. Soon the State had to realise that it could not create its project around a collection of players with the necessary resourses.

First, the support of the Region was critical for the State, because the Region was the public transport authority and as such controlled the planning and development of the existing network, and managed significant financial resourses. Its support was all the more crucial since the State had no money (it could barely fund 1 billion out of the 25 billion EUR needed to construct the GPE). Several business asssociations urged a compromise with the region in order to overcome the stalemate. In 2011 a compromise between the State and the Region was concluded and a new project, the Grand Paris Express (GPE) which is a combination of the 'Big 8' and Arc Express was approved.

Second, the State thought it could enroll some local authorities of the left by 'buying them off' with CDT funding. As the CDT was a contract in which the State could directly provide money to municipalities and did not have to comply with the SDRIF, it could be used to create some allies, included the leftist governments. This partly succeeded when one of the first CDTs was signed in 2011 with Plaine Commune, the most important municipal joint authority of the Ile de France composed of municipalities controlled by the left.

However, the conservative government did not have time to pursue this strategy ${ }^{4}$. It was defeated in the 2012 national elections and a new government, socialist, i.e. of the same political leaning as the regional council, the city of Paris and other local governments, was formed. It was much more supportive of decentralisation that the previous conservative one and less brutal in its approach of the relationships with local governments. A larger compromise was found between the SGP and the regional council with the "New Greater Paris Project's, the CDTs were opened to the départements and the Region and they were required to comply with the regional master plan.

\section{The Métropole du Grand Paris, the Governance of the Core?}

The necessity to change the institutional system of the metropolitan area gained momentum in the early 2000s. Although the idea of changing the governance of the metropolitan area was largely shared by many players, the reasons to do so varied according to the concerns of key actors. International competition was clearly an argument for the State, and was without surprise endorsed by the major business associations, notably the Medef, PICE and the chamber of commerce of Paris. But for many local governments, notably the city of Paris and the départements controlled by the left, priority for reform was - as we have seen - not international competition but the necessity to reduce social and 
territorial inequalities that some local authorities believed to be due to globalisation (i.e. international competition in their understanding).

Besides arguments related to globalisation, the conflict around institutional reform also had some decentralisation components. On one hand, most local governments, be they conservative or progressive, were afraid of a State imposed institutional scheme. This became all the more relevant when some bottom up initiatives - like the metropolitan conference and Paris Métropole - were underway. They claimed that the only solution was voluntary cooperation among stakeholders. Although most local authorities welcomed the new attention on the Ile de France shown by the State, they were keen to assert that this should be done with respect to the principles of decentralisation. If the most active local governments in this regard were the city of Paris, the Region and the progressive départements, they were also supported by some conservative authorities. In addition, the Region strongly claimed that if a reform was needed, it was not to be made to the detriment of the Region because "the metropolis is the region" and from that perspective the reform should increase regional powers (Lefèvre 2017).

\section{The Creation of the Métropole du Grand Paris}

The conservative government did not push for the reform and prefered to focus on the Grand Paris Project and specifically on the Big 8 which was already very controversial. But after the 2012 national elections, the institutional reform was put back in the agenda by the new socialist government as part of a more comprehensive political and administrative reform alongside a series of decentralisation acts. In january 2014 with the approval of the MAPTAM ${ }^{6}$ Act, a new authority was established, the Métropole du Grand Paris (MGP).

The territory covered by the MGP represents, more or less, the core of the metropolitan area: Four départements of the so called petite couronne (first ring) and a few adjacent municipalities. This perimeter was not chosen by chance but was the result of a long process and a long battle. Indeed, right from the beginning of the elaboration of the regional master plan (SDRIF) in 2005, the city of Paris pushed for special treatment of the core area (more or less defined as the first ring). The arguments were that the core contained $47 \%$ of the regional population, $60 \%$ of regional jobs, $80 \%$ of public transport trips as contrasted with only $4 \%$ of the Ile de France. In november 2005, the city of Paris succeeded in obtaining agreement, that the 'dense zone' as it was then called would be considered specifically in the planning reflections of the regional council. (Figure 3 here)

Between 2007 and 2012, several proposals to merge the four départements of the first ring or to have specific institutional treatment of this area (Dallier, 2008) were discussed. None were accepted. After the 2012 national election, the situation changed, largely because the Socialist government had put this issue high on its agenda. 
The MAPTAM Act set up a strong authority. Its territory only covered the core of the Ile de France region: The 4 central départements and 131 municipalities (see Figure 3), containing only 7 million people. However, its powers were to be significant (planning, environment, housing, culture, economic development) as were its resources (own taxes which previously were levied by local authorities). It was clear that these powers and resourses were to be taken from existing local authorities, with the exception of the Region. In addition, the MGP was to be run by a council of indirectly elected members, initially appointed by the municipalities. This was to change in 2020 (year of the next municipal elections) with a council directly elected by the people. The MGP was to be divided into twelve 'territories' (see Figure 4), each grouping several municipalities, these 'territories' would have no resourses or powers of their own other than those to be voluntarily delegated by the MGP. Legally speaking they were not authorities but merely cooperative units imposed by the law. Finally, the MAPTAM Act set up a governance structure linking the MGP with the second ring of the Ile de France through a so called metropolitan conference, composed of the MGP, the Region and the four remaining départements of the second ring, which had no powers or resourses and was merely a structure meant for the purpose of dialogue. (Figure 4 here)

To sum up, the MGP would be a powerful institution, holding a strong political legitimacy from 2020 on and covering the economic heart of the region. This did not please many players.

\section{The Battle over the MGP}

Right from the enactment of the law, local governments unanimously endeavored to reduce the power and resources of the MGP. Taking advantage of the elaboration of a new law on decentralisation due to be approved in 2015, they put pressure on the government to do so, and they succeeded. In the 2015 decentralisation Act $\left(\mathrm{NoTRE}^{7}\right)$, the 'territories' acquired the status of authorities with their own powers and resources, largely taken from the MGP which became a weak authority with a budget of about 80 million EUR (MGP 2017) as contrasted with an estimated budget of several $€$ billions previously. The city of Paris is itself a 'territory' and with 62 councillors out of 209, it represents by far the largest institutional power.

From the very beginning the State was reluctant to modify the MAPTAM act as regards the MGP. It wanted a strong authority and was supported by the largest business associations and the chamber of commerce which urged the national government to resist the pressure of local authorities. They denounced the weak MGP as a "metropolis with small feet" and claimed that a strong MGP was needed in order "to achieve the objectives of development and economic attractiveness put forward in the law" (Métropole du Grand Paris: le "coup de gueule" du président de la CCI Paris Ilede-France, 2015 This quote comes from the Blog of P. Mansat, the deputy mayor of Paris. So there is no page number). In vain. 
At the time of writing, the conflict goes on and has been revived by the new conservative regional council, elected in December 2015. Once again the issues of international competitiveness and governance in the Ile de France has been raised by business associations and the chamber of commerce, who published a joint report on these topics (CRCI, Medef, Cgmpe 2015). The new President of the Region has insisted on the need for such a reopening on the grounds that "the good scale for the metropolitan fact is the region. The Greater London or Asiatic metropolises encompass between 8 and 15 million inhabitants. If we take the Ile de France as a whole, that is 12 million people, we would be in the first places in many international rankings. But, with the MGP, which I call the "shrunk Grand Paris", we have 7 million and we are located at the bottom of all these rankings" ( $L a$ métropole est une création politicienne, 2016). In July 2017, the newly elected President of the Republic, Emmanuel Macron, decided to convene a "territorial conference of the Grand Paris" in autumn 2017, arguing that "if we want the Grand Paris to win international competition, if we want to produce wealth in order to harmoneously redistribute it on the territory, we need to drastically simplify the structures." (Conférence nationale des territoires, July 18, 2017 no page number here since it is the introductory speech of the President). The battle over the MGP is clearly not finished.

\section{Conclusion}

The efforts to construct a metropolitan space in the Paris region offers a very interesting example of the contestation over scalar processes. Many competing conceptions of metropolitan space are copresent and are conflicting. First the regional council, whatever its political leaning, has always considered the Metropolis to be the Ile de France region. In that perspective the construction of metropolitan space is understood to mean the strengthening of the powers and resourses of the regional authority. Secondly, the city of Paris, although being cautious to not precisely define the perimeter of the metropolitan area, considers the core area, roughly the first ring, to be the most relevant space to address the important problems of the metropolis. Thirdly, the State maintains an ambiguous position as regards its conception of the metropolitan space. In the period 2007-2012 when the State was controlled by the conservative parties, metropolitan space meant the city region with no precise definition beyond the functional area covered by the 'Big 8', that is airports and major transport nodes and major clusters. In the period 2012-2017, the Socialist government seemed to restrain the metropolitan space to the core area of the Ile de France, although the MAPTAM Act also set up institutional relations to generate dialogue between the core and the second ring of the region with the metropolitan conference. Finally, the most important business associations, although not being particularly interested in institutional change in the perimeters, have been ready to accomodate any initiative, provided that the treatment of the most important issues of economic competitiveness, transport and housing were taken care of. 
This story clearly indicates the importance of politics in the construction of metropolitan space and shows the critical role that politics plays in shaping scalar conflicts. In this context, decentralisation and globalisation can be understood to be both structuring forces as well as elements which are instrumentalised. First, there is the issue of territorial leadership which in the Ile de France, has consistently led to a stalemate, because of a governance system whose main feature, unregulated competitive decentralisation (Lefèvre 2012), prevents any leader from being accepted as legitimate at a regional scale. Secondly, the building of a coalition at the metropolitan level, to ensure capacity to act at that scale, has proved impossible. First because of the relatively even balance of powers between local governments (i.e. no hierarchy), and second because of the incapacity of the State to succesfully act as the leader of a coalition because of its political instability and its lack of resourses. Thirdly, players also conflict about the vision they have of the future of the metropolitan area. Two clearly opposed visions co-exist, one in which priorities are to fight against social and territorial inequalities and to initiate an alternative mode of development based on ecological transition, another one in which economic competitiveness is the top priority to which social, territorial and environmental issues must be subordinated. Since these two visions are supported by alliances of players which are roughly equal in strength, the not surprising result is conflict, stalemate, and the blockage of the governance system.

The Paris-Ile de France case then shows the inability of a system of players to produce a capacity to act, that is, to address the most acute issues posed to a global city, because it has proved unable to generate an alliance between players under the form of a growth coalition or an urban regime. In this context, the attempts to change the scale(s) of urban governance has been particularly significant as an heuristic tool to analyze today's urban power because it shows that, at least in the Paris-Ile de France case, rescaling is a much contested process which can reach a stalemate.

\section{Notes}

Solidarité et Renouvellement Urbain (SRU) Act.

The La Défense CBD is the largest CBD in Europe. It is located in the west and wealthiest part of the region. Urban Community: a strong joint authority with important competences delegated by the member municipalities (public transport, planning culture, economic development, waste management, etc.) and its own fiscal resourses.

4 The Ministry for the development of the capital region was abolished in 2010 after a political scandal.

5 The New Greater Paris Project is a combination of the GPE and a betterment of the regional existing public transport network through State, Regional and local authorities funding.

6 MAPTAM stands for Modernisation de l'Action Publique Territoriale et Affirmation des Métropoles. It set up new metropolitan authorities in the 10 largest urban areas, with specific features for Lyon, Marseille and Paris.

7 NoTRE for Nouvelle Organisation Territoriale de la République : New Territorial Organisation of the Republic which reduces the number of Regions and slightly increase their powers

\section{References}


Clark, G. and Moonen, T. (2013) "The Business of Cities: What Do 150 City Indexes and Benchmarking Studies Tell Us About the Urban World in 2013?" Jones Lang Lasalle, Conférence nationale des territoires, July 18, 2017.

Conférence nationale des territoires, july 18, 2017 I don’t know how to present it. It was a conference convoked by the President. Is there a specific way to put it as a reference ?

Conseil Régional d’Ile de France (2008) Scenarii pour la métropole Ile de France Demain, xxx.

Conseil Régional d'Ile de France (2013) Schéma Directeur de la Région Ile de France, défis en enjeux, Paris.

Dallier, X. (2008) Les perspectives d'évolution institutionnelle du Grand Paris: Rapport d'information: $n^{\circ} 262$, april 2008: Sénat.

Gilli, F. (2014) Grand Paris: l'émergence d'une métropole, Paris: Les Presses de Sciences Po.

Grand Paris Développement (2016) "La métropole est une création politicienne," available at: http://grandparisdeveloppement.com/grand-entretien-avec-valerie-pecresse/ (accessed June 6, 2016).

Le Galès, P. (2002) European Cities, Social Conflicts and Governance, Oxford: Oxford University Press.

Lefèvre, C. (2012) "Paris-Ile de France: Unregulated Competitive Decentralization," in P. Kantor et al., Struggling Giants, City Region Governance of London, New York, Paris and Tokyo, Minneapolis: University of Minnesota Press: xxx-xxx.

Lefèvre, C. (2017) Paris, métropole introuvable; le défi de la globalisation, Paris: PUF, collection Villes en débat.

Logan, J. and Molotch, H. (1987) Urban Fortunes: The Political Economy of Place, Berkeley: University of California Press.

MEDEF Ile de France, CCI Paris Ile de France, CGPME (2015) Faire respirer Paris, Paris.

Métropole du Grand Paris: le "coup de gueule" du président de la CCI Paris Ile-de-France (2015), retrieved from http://www.pierremansat.com/2015/03/metropole-du-grand-paris-le-coup-degueule-du-president-de-la-cci-paris-ile-de-france.html (accessed july 8, 2017)

MGP (2017) Annual report 2016, Paris.

Paris Métropole (2012) Livre (ou)vert: pour une métropole durable, quelle gouvernance ?, Paris.

Présidence de la République (2008) Lettre de mission de Christian Blanc, xxx.

Stoker, G. and Mossberger, K. (1994) "Urban Regime Theory in Comparative Perspective," Environment and Planning C: Government and Policy, 12(2): 195-212.

Stone, C. (1993) "Urban Regimes and the Capacity to Govern: A Political Economy Approach," Journal of Urban Affairs, 15(xxx): 1-28.

Subra, P. (2012) Le Grand Paris, Géopolitique d'une métropole mondiale, Paris: Armand Colin. 